\title{
Haemophilus avium, a New Species from Chickens
}

\author{
K.-H. HINZ AND CHANTANA KUNJARA
}

Institute for Poultry Diseases, The School of Veterinary Medicine, Hannover, Federal Republic of Germany

Twelve Haemophilus strains (previously designated group II strains by Hinz) from chickens and of uncertain taxonomic position and 29 Haemophilus paragallinarum strains were investigated. The findings indicate the existence of a hitherto unknown species, for which the name Haemophilus avium sp. nov. is proposed. The main characters which differentiate $H$. avium from $H$. paragallinarum are as follows: all of the $H$. avium but none of the $H$. paragallinarum strains tested produce catalase, alkaline phosphatase, and $\alpha$-glucosidase, acidify galactose and trehalose, and do not require serum for optimal growth. Most of the $H$. avium strains produce yellow pigment, grow aerobically, and do not require $\mathrm{CO}_{2}$ for optimal growth. In further contrast to $\mathrm{H}$. paragallinarum, none of the $H$. avium strains are able to cause infectious coryza of chickens. The type strain of H. avium is IPDH 2654 (= ATCC 29546).

De Blieck (5), Nelson (20), and Elliot and Lewis (8) were the first to report on the etiology of the specific disease of chickens known as Coryza infectiosa gallinarum. The name now used for this disease, infectious coryza, was introduced by Schalm and Beach (26). Infectious coryza is world-wide in distribution and is of economic importance wherever chickens are raised. De Blieck named the causative agent Bacillus haemoglobinophilus coryzae gallinarum, and later Delaplane et al. (6) named it Haemophilus gallinarum, by which name it is currently cited in Bergey's Manual of Determinative Bacteriology (23). Schalm and Beach (25, 26) and Delaplane et al. (7) found that their strains required $\mathrm{X}$ and $\mathrm{V}$ factors for growth. Later, this finding could not be confirmed by other workers $(1,9,21)$, who showed that the coryza-producing agent requires only $\mathrm{V}$ factor for growth. Biberstein and White (2), therefore, proposed the name Haemophilus paragallinarum for X-factor-independent haemophili which are able to cause infectious coryza of chickens. In Bergey's Manual (30) and in Cowan and Steel's manual (4), $H$. paragallinarum was included in the genus Haemophilus as a recognized species.

Furthermore, there are X-factor-independent haemophili in chickens which differ from $H$. paragallinarum in their pathogenicity (they are unable to produce infectious coryza) and in their physiological, biochemical and serological features. To date, these haemophili have been unnamed and unclassified $(9,16,21,24)$. Consequently, a study was undertaken to determine the taxonomic relationship of these organisms, and the results of this study are presented herein.

\section{MATERIALS AND METHODS}

Bacterial strains. The designations and sources of the strains used in this study are listed in Table 1 . Cultures of the strains were stored in the freeze-dried state until needed.

Morphological, physiological, and biochemical tests. The morphologies of cells and colonies and the staining reactions (Gram and capsule staining) were determined as described by Hinz (9).

The morphologies and the requirement for $\mathrm{V}$ and $X$ factors were determined by use of the following basic media: (i) proteose peptone agar consisted of $2.0 \%$ (wt/vol) proteose peptone no. 3 (Difco), $0.6 \%$ $(\mathrm{wt} / \mathrm{vol}) \mathrm{NaCl}, 0.5 \%(\mathrm{wt} / \mathrm{vol})$ glucose, and $1.0 \%$ (wt/vol) Noble agar; the final $\mathrm{pH}$ was 7.2 to 7.3 ; (ii) tryptose agar (Difco); the final $\mathrm{pH}$ was 7.2 to 7.3 ; (iii) brain heart infusion agar (BHIA) (Difco); the final pH was 7.2 to 7.3 .

The media were adjusted to $\mathrm{pH} 7.6$ with $1 \mathrm{M} \mathrm{NaOH}$ and were then autoclaved for $10 \mathrm{~min}$. $\mathrm{X}$ factor and serum $(\mathrm{X}, \mathrm{S})$, or $\mathrm{X}$ and $\mathrm{V}$ factors $(\mathrm{X}, \mathrm{V})$, or $\mathrm{V}$ factor (V) or $\mathrm{V}$ factor and serum $(\mathrm{V}, \mathrm{S})$ were added to each medium. A filter-sterilized solution of $\beta$-nicotinamide adenine dinucleotide (NAD) (Serva) and cysteine-hydrochloride (Merck) was added to give a final concentration of $100 \mu \mathrm{g} / \mathrm{ml}$ for both substances. Hemin (Roth) dissolved in triethanolamine (Kodak) was added as a filtered solution to give a final concentration of $10 \mu \mathrm{g} / \mathrm{ml}$ of medium. The chicken sera added to the media were free of agglutinating antibodies against the Haemophilus strains used. Inoculated media were incubated aerobically, microaerophilically (90\% air and $10 \% \mathrm{CO}_{2}$ [vol/vol]), and anaerobically (BBL-Gas Pak 110 System) for 24 and $48 \mathrm{~h}$ at $37^{\circ} \mathrm{C}$. The results were evaluated as described by Zinnemann et al. (31). Haemophilus influenzae strain TS 43 was used as a control.

The ability to synthesize porphyrin from $\delta$-aminolevulinic acid was determined as described by Kilian (15).

For satellite growth and hemolysis, 24- to 48-h-old 
TABLE 1. Strains utilized in this study

\begin{tabular}{|c|c|c|c|}
\hline $\begin{array}{l}\text { Strain no. in } \\
\text { this study }\end{array}$ & Name as received & Isolated from: & Source and strain designation ${ }^{a}$ \\
\hline TS1 & Haemophilus sp. & Chicken, air sac & IPDH $1762 ;$ serovar $1(9-11)$ \\
\hline TS2 & Haemophilus sp. & Chicken, air sac & IPDH 64; serovar $1(9-11)$ \\
\hline TS3 & Haemophilus sp. & Chicken, infraorbital sinus & IPDH 2654 ; serovar $2(9-11)$ \\
\hline TS4 & Haemophilus sp. & Chicken, lung & IPDH $2659 ;$ serovar $2(9-11)$ \\
\hline TS5 & Haemophilus sp. & Chicken, nose & IPDH 780; serovar $3(9-11)$ \\
\hline TS6 & Haemophilus sp. & Chicken, infraorbital sinus & IPDH 94; serovar $4(9-11)$ \\
\hline TS7 & Haemophilus sp. & Chicken, infraorbital sinus & IPDH 1254; (9-11) \\
\hline TS8 & Haemophilus sp. & Chicken, wattle & IPDH 0003 (Hinz) \\
\hline TS9 & Haemophilus sp. & Chicken, heart & IPDH 0002 (Hinz) \\
\hline TS10 & Haemophilus sp. & Chicken, infraorbital sinus & IPDH 280 (Hinz) \\
\hline TS11 & Haemophilus sp. & Chicken, infraorbital sinus & IPDH 331A (Hinz) \\
\hline TS12 & Haemophilus sp. & Chicken, infraorbital sinus & IPDH 306 (Hinz) \\
\hline TS13 & H. gallinarum & & ATCC $14385(=$ NCTC 3438$)$ \\
\hline $\operatorname{TS} 14^{a}$ & H. gallinarum & Chicken, respiratory tract & L. A. Page $(21,22)$; 0083; serovar A \\
\hline $\operatorname{TS} 15^{a}$ & H. gallinarum & Chicken, respiratory tract & L. A. Page $(21,22) ; 0222 ;$ serovar B \\
\hline $\operatorname{TS} 16^{a}$ & $H$. gallinarum & Chicken, respiratory tract & R. Yamamoto (27); 17756 \\
\hline TS17 & H. paragallinarum & Chicken, sinus exudate & IPDH $1645 ;$ serovar A $(9-11)$ \\
\hline TS18 & H. paragallinarum & Chicken, eye & IPDH 2213 ; serovar A $(9,10)$ \\
\hline TS19 & H. paragallinarum & Chicken, air-sac exudate & IPDH 1646 ; serovar A $(9,10)$ \\
\hline TS20 & H. paragallinarum & Chicken, sinus exudate & IPDH 1598 ; serovar A $(9,10)$ \\
\hline TS21 & H. paragallinarum & Chicken, sinus exudate & IPDH $6001 ;$ serovar A $(9-11)$ \\
\hline TS22 & H. paragallinarum & Chicken, sinus exudate & $\begin{array}{l}\text { IPDH } 2403(=\text { ATCC } 29545) \text {; sero- } \\
\quad \text { var B }(9-12)\end{array}$ \\
\hline TS23 & H. paragallinarum & Chicken, sinus exudate & IPDH $2671 ;$ serovar B $(9,10)$ \\
\hline TS24 & H. paragallinarum & Chicken, sinus exudate & IPDH 1676 ; serovar B $(9,10)$ \\
\hline TS25 & H. paragallinarum & Chicken, sinus exudate & IPDH $2025 ;$ serovar B $(9,10)$ \\
\hline TS26 & H. paragallinarum & Chicken, sinus exudate & IPDH 2028; serovar B $(9,10)$ \\
\hline TS27 & $H$. paragallinarum & Chicken, sinus exudate & IPDH $733 ;$ serovar B $(9,11)$ \\
\hline TS28 & H. paragallinarum & Chicken, air-sac exudate & IPDH 2820 ; serovar B $(9,10)$ \\
\hline TS29 & H. paragallinarum & Chicken, nose exudate & IPDH $2600 ;$ serovar B $(9,10)$ \\
\hline TS30 & H. paragallinarum & Chicken, sinus exudate & IPDH $1655(9,10)$ \\
\hline TS31 & H. paragallinarum & Chicken, sinus exudate & IPDH $1596(9,10)$ \\
\hline TS32 & H. paragallinarum & Chicken, sinus exudate & IPDH $782(9,10)$ \\
\hline TS33-42 & Haemophilus sp. & Chickens, sinus exudate & IPDH, isolated recently (Hinz) \\
\hline TS43 & H. influenzae & & HIM-417.7 \\
\hline TS44 & H. parainfluenzae & & ATCC 9796 \\
\hline TS45 & H. suis & & ATCC 19417 \\
\hline TS46 & H. parasuis & Pig lung & G. Amtsberg; 3327 \\
\hline TS47 & Escherichia coli & & IPDH; field strain \\
\hline TS48 & $\begin{array}{l}\text { Yersinia pseudotuber- } \\
\quad \text { culosis }\end{array}$ & & IPDH; field strain \\
\hline TS49 & $\begin{array}{l}\text { Staphylococcus epider- } \\
\quad \text { midis }\end{array}$ & & IPDH; field strain \\
\hline
\end{tabular}

${ }^{a}$ Strains received from R. Yamamoto, Department of Epidemiology and Preventive Medicine, School of Veterinary Medicine, University of California, Davis, Calif.

Abbreviations: ATCC, American Type Culture Collection, Rockville, Md.; IPDH, Institute for Poultry Diseases, Hannover, Germany; G. Amtsberg, Institute for Microbiology and Epidemic Animal Diseases, Hannover, Germany; HIM, Collection of the Hygiene-Institute, Marburg, Germany.

growth was examined on blood agar containing Columbia agar base (Oxoid) and $7 \%(\mathrm{wt} / \mathrm{vol})$ defibrinated ox blood. A Staphylococcus epidermidis strain (TS 49) was used as a V-factor feeder.

Oxidase was tested for by Kovács's method (18).

Catalase activity was determined using tryptose agar-(X, V, S) and BHIA-(X, V, S) cultures which were incubated under microaerophilic and/or aerobic conditions. In testing for catalase, a few colonies were removed with a cover slip and mixed in a drop of $3 \%$ (vol/vol) $\mathrm{H}_{2} \mathrm{O}_{2}$. The production of bubbles was regarded as a positive test for catalase.
Indole production was demonstrated, using Kovács's reagent (4), in tryptose broth (Difco) with 50 $\mu \mathrm{g}$ of NAD per $\mathrm{ml}$ and $1 \%$ chicken serum after 1 and 3 days of growth.

Reduction of nitrate and nitrite was tested as described by Cowan (4) by use of the same tryptose broth as above but with $0.1 \% \mathrm{KNO}_{3}$.

The production of urease was determined as described by Lautrop (19).

Alkaline phosphatase was determined by the method of Kersters and DeLey (14).

Determination of the enzymes $\alpha$-fucosidase and $\alpha$ - 
glucosidase was performed by the method of Kilian and Bülow (17) and Kilian (16), using $p$-nitrophenyl- $\alpha$ L-fucopyranoside and $p$-nitrophenyl- $\alpha$-D-glucopyranoside (Serva) as substrates. $H$. parainfluenzae strain TS 44 and Escherichia coli strain TS 47 were used as positive controls for the $\alpha$-glucoside test. One Yersinia pseudotuberculosis strain (TS 48), H. parasuis TS 46 , and strain TS 45 , listed as $H$. suis, acted as positive controls for the production of $\alpha$-fucosidase.
Acid production from carbohydrates (Merck) was determined in phenol red broth base (Difco).

The base medium together with the carbohydrate (Table 2) and $1 \%$ (vol/vol) chicken serum was filtersterilized through $0.2-\mu \mathrm{m}$-pore-size filters. The different test media were dispensed in 5 -ml volumes in test tubes, and Durham tubes were inserted in the glucose medium for the detection of gas. The bacterial inoculum was added simultaneously with neutralized NAD

TABLE 2. Characteristics of 13 previously unidentified strains of haemophili (includes ATCC 14385) and of 29 Haemophilus paragallinarum strains from chickens ${ }^{a}$

\begin{tabular}{|c|c|c|c|c|c|c|c|c|c|c|c|c|c|c|}
\hline \multirow{2}{*}{ Characteristic } & \multicolumn{13}{|c|}{ Previously unidentified strains } & \multirow{2}{*}{$\begin{array}{l}\text { H. paragalli- } \\
\text { narum strains } \\
\text { TS14-TS42 }\end{array}$} \\
\hline & TS13 & TS3 & TS4 & TS1 & TS2 & TS5 & TS6 & TS7 & TS8 & TS9 & TS10 & TS11 & TS12 & \\
\hline $\mathrm{X}$-factor requirement & - & - & - & - & - & - & -. & - & - & - & - & - & - & $-(0)^{b}$ \\
\hline $\begin{array}{l}\delta \text {-Aminolevulinic utiliza- } \\
\text { tion }\end{array}$ & + & + & + & + & + & + & + & + & + & + & + & + & + & $+(29)$ \\
\hline$V$-factor requirement & + & + & + & + & + & + & + & + & + & + & + & + & + & $+(29)$ \\
\hline Aerobic growth & + & + & + & + & + & + & + & + & + & + & + & + & + & $-(0)$ \\
\hline Anaerobic growth & + & + & + & + & + & + & + & + & + & + & + & + & + & $+(29)$ \\
\hline $\mathrm{CO}_{2}$ requirement & - & - & - & - & - & - & - & - & - & - & $+{ }^{\prime \prime}$ & $+{ }^{c}$ & - & $+(29)$ \\
\hline Serum requirement & - & - & - & - & - & - & - & - & - & - & - & - & - & $-/+(6)$ \\
\hline Serum improves growth & - & - & - & - & - & - & - & - & - & - & - & - & - & $+(29)$ \\
\hline Hemolysis & - & - & - & - & - & - & - & - & - & - & - & - & - & $-(0)$ \\
\hline $\begin{array}{l}\text { Yellow-pigment produc- } \\
\text { tion }\end{array}$ & + & - & + & + & + & + & + & + & + & + & + & + & + & $-(0)$ \\
\hline Nitrate reduction & + & + & + & + & + & + & + & + & + & + & + & + & + & $+(29)$ \\
\hline Indole production & - & - & - & - & - & - & - & - & - & - & - & - & - & $-(0)$ \\
\hline Urease & - & - & - & - & - & - & - & - & - & - & - & - & - & $-(0)$ \\
\hline Oxidase & - & - & - & - & - & - & - & - & - & - & - & - & - & $-(0)$ \\
\hline Catalase & + & + & + & + & + & + & + & + & + & + & + & + & + & $-(0)$ \\
\hline Alkaline phosphatase & + & + & + & + & + & + & + & + & + & + & + & + & + & $-(0)$ \\
\hline $\mathrm{ONPG}^{d} \beta$-galactosidase & + & - & - & - & - & + & - & + & + & - & - & - & - & $-(0)$ \\
\hline$\alpha$-Fucosidase & - & - & - & - & - & - & - & - & - & - & - & - & - & $-(0)$ \\
\hline $\mathrm{PNPG}^{e} \alpha$-glucosidase & + & + & + & + & + & + & + & + & + & + & + & + & + & $-/+(3)$ \\
\hline Pathogenicity $f$ & - & - & - & - & - & - & - & - & - & - & - & - & - & $+(29)$ \\
\hline Acid from: & & & & & & & & & & & & & & \\
\hline Maltose & + & + & + & + & + & + & + & + & + & + & + & + & + & $+(29)^{b}$ \\
\hline Fructose & + & + & + & + & + & + & + & + & + & + & + & + & + & $+(29)$ \\
\hline Mannose & + & + & + & + & + & + & + & + & + & + & + & + & + & $+(29)$ \\
\hline Saccharose & + & + & + & + & + & + & + & + & + & + & + & + & + & $+/-(27)$ \\
\hline Galactose & + & + & + & + & + & + & + & + & + & + & + & + & + & $-(0)$ \\
\hline Trehalose & + & + & + & + & + & + & + & + & + & + & + & + & + & $-(0)$ \\
\hline Mannitol & + & - & + & - & + & + & + & + & + & - & + & + & - & $+(29)$ \\
\hline Sorbitol & - & - & - & - & - & - & - & + & + & - & - & - & - & $+(29)$ \\
\hline Dextrin & + & + & + & + & + & + & + & + & + & - & + & + & + & $+(29)$ \\
\hline Xylose & + & - & + & - & - & + & + & - & + & + & - & - & - & $-/+(6)$ \\
\hline Lactose & - & - & - & - & - & + & - & + & - & - & - & - & - & $-(0)$ \\
\hline Cellobiose & - & - & - & - & - & + & - & - & - & - & - & - & - & $-(0)$ \\
\hline Arabinose & - & - & - & + & + & - & + & - & - & - & + & + & + & $-(0)$ \\
\hline Salicin & - & - & - & - & - & - & - & - & - & - & - & - & - & $-(0)$ \\
\hline Inulin & - & - & - & - & - & - & - & - & - & - & - & - & - & $-(0)$ \\
\hline Deoxyribose & - & - & - & - & - & - & - & - & - & - & - & - & - & $-(0)$ \\
\hline Glucose, gas & - & - & - & - & - & - & - & - & - & - & - & - & - & $-(0)$ \\
\hline Glucose, acid & + & + & + & + & + & + & + & + & + & + & + & + & + & $+(29)$ \\
\hline
\end{tabular}

${ }^{a}$ Symbols: + , positive result (with respect to acid production from carbohydrates, + indicates a final $\mathrm{pH}$ of $<6.5$ ); - , negative result.

${ }^{b}$ Numbers in parentheses are numbers of strains positive for the characters indicated.

${ }^{c}$ These strains required $\mathrm{CO}_{2}$ on primary isolation.

${ }^{d}$ ONPG, $\alpha$-nitrophenyl- $\beta$-D-galactopyranoside.

e PNPG, $p$-nitrophenyl- $\beta$-D-glucoside.

$f$ Ability to produce infectious coryza in chickens. 
solution to give a final concentration of $50 \mu \mathrm{g}$ of NAD per $\mathrm{ml}$ of medium. Each of the tubes was inoculated with $0.05 \mathrm{ml}\left(>10^{6}\right.$ colony-forming units per tube) of a bacterial suspension in $0.15 \mathrm{M} \mathrm{NaCl}$ made from 16 to 24-h-old BHIA-(V, S) cultures. Uninoculated tubes incubated under the same condition as described above served as controls. The final reactions were measured with a $\mathrm{pH}$ meter after 24 and $48 \mathrm{~h}$ of incubation.

The pathogenicity tests were performed as described by Hinz (11). Eight-week-old chickens free of avian encephalomyelitis virus, adenovirus, infectious bronchitis virus, Newcastle disease virus, respiratory enteric orphan virus, Marek disease herpesvirus, laryngotracheitis virus, Rous sarcoma virus, infectious bursal disease virus, influenza virus A, fowlpox virus, Mycoplasma gallisepticum, Mycoplasma synoviae, Salmonella gallinarum, and S. pullorum were used. Haemophilus cells used for inoculation of the chickens were obtained from 8- to 10-h-old BHIA- $(\mathrm{V}, \mathrm{S})$ cultures and were suspended in phosphate-buffered saline (pH 7.2) with $1 \%$ chicken serum and $10 \mu \mathrm{g}$ of NAD per $\mathrm{ml}$. Haemophilus cells used for inoculation were not washed. To test for the ability to cause infectious coryza, more than $5 \times 10^{7}$ colony-forming units in 0.05 $\mathrm{ml}$ of inoculum was instilled into nostrils and on the mucous membranes of the birds. Each of the Haemophilus strains was tested in five birds. A suspension of each Haemophilus strain inactivated at $100^{\circ} \mathrm{C}$ for $10 \mathrm{~min}$ was inoculated into two control chickens housed separately from the infected groups. Inoculated chickens were examined for clinical signs every day for 14 days. Necropsied birds were then examined for gross pathological changes, and samples from the respiratory tract were cultured for haemophili.

\section{RESULTS}

The characteristics of the Haemophilus strains studied are presented in Tables 2 and 3. On the basis of their characteristics, the strains studied fell into two groups: one group contains all of the strains of $H$. paragallinarum; the other contains the strains TS1 to TS12 inclusive and ATCC 14385 (TS13) which could not be assigned to one of the known Haemophilus species.

The characteristics of these unidentified strains (TS1 to TS13, inclusive) are as follows: Gram-negative, coccoid to pleomorphic, nonmotile, nonsporeforming rods $(0.4$ to 0.5 by 0.9 to $3.0 \mu \mathrm{m}$ ), which occur singly, in pairs, and in filamentous forms. Strains TS1 to TS6, inclusive, and TS9 to TS12, inclusive, formed smooth, convex, grayish-white or yellowish opaque colonies with entire edges on BHIA- $(\mathrm{V}, \mathrm{S})$. Colonies of strains TS7 and TS8 were wrinkled and gave lumpy suspensions in a $0.15 \mathrm{M} \mathrm{NaCl}$ solution. TS13 formed rough colonies with a granular surface. All of the strains except TS13 were encapsulated and showed iridescence on transparent solid media in oblique transmitted light
TABLE 3. Characteristics useful in differentiating Haemophilus avium sp. nov. from H. paragallinarum ${ }^{a}$

\begin{tabular}{|c|c|c|}
\hline Characteristic & $\begin{array}{l}\text { H. av } \\
\text { ium }\end{array}$ & $\begin{array}{l}\text { H. para- } \\
\text { gallinarum }\end{array}$ \\
\hline Aerobic growth & $+1-$ & - \\
\hline $\mathrm{CO}_{2}$ requirement & $-1+$ & + \\
\hline Serum improves growth & - & + \\
\hline $\begin{array}{l}\text { Yellow-pigment produc- } \\
\text { tion }\end{array}$ & $+1-$ & - \\
\hline Catalase & + & - \\
\hline Alkaline phosphatase & + & - \\
\hline \multicolumn{3}{|l|}{ Acid from: } \\
\hline Trehalose & + & - \\
\hline Galactose & + & - \\
\hline$\alpha$-Glucosidase (PNPG) & + & $-1+$ \\
\hline Pathogenicity ${ }^{b}$ & - & + \\
\hline
\end{tabular}

${ }^{a}$ Symbols: $+/-$, most strains are positive; $-/+$, most strains are negative; + , positive result; - , negative result.

${ }^{b}$ Produces infectious coryza in chickens.

throughout the first 8 to $14 \mathrm{~h}$ of incubation. Iridescence disappeared completely after $36 \mathrm{~h}$ of incubation. Most of the strains did not require $\mathrm{CO}_{2}$ for luxuriant growth in serial passages on solid media. However, strains TS10 and TS11 required increased $\mathrm{CO}_{2}$ tension on primary isolation. Subcultures made from single colonies of those isolates on BHIA-(V, S) gave aerobic growth of a few colonies which did not require increased $\mathrm{CO}_{2}$ tension in continued passages. It is probable that this adaptation was caused by dissociation. Since the properties of TS10 and TS11 were otherwise similar to those of the other strains, they were retained in the group of unidentified strains. All of the strains showed satellite phenomenon after microaerobic or aerobic incubation on ox blood agar streaked with a strain of Staphylococcus aureus as a V-factor feeder. They required the $\mathrm{V}$ factor but not the $\mathrm{X}$ factor or serum for growth. X-factor independence was confirmed by the ability of these strains to carry out biosynthesis of porphyrin from $\delta$-aminolevulinic acid. In phenol red base, acid was produced from carbohydrates in an amount sufficient to give a clear-cut change of the indicator $(\mathrm{pH}<6.5)$ after 1 to 2 days of incubation. The decrease of $\mathrm{pH}$ in carbohydrateand serum-free phenol red broth produced by some of the unidentified strains reached only $0.6 \mathrm{U}$. All strains were catalase and phosphatase positive and produced acid from trehalose and galactose; some of the strains also produced acid from lactose, cellobiose, and arabinose. Four of the 13 strains produced $\beta$-galactosidase. In tryptose peptone broth, used as the basal medium for sugar fermentation in a previous study by Hinz (9), fewer strains produced acid from mal- 
tose, dextrin, and xylose than in phenol red basal medium. None of the strains produced clinical or pathological signs in chickens. Infectious coryza could not be produced with any of these strains.

\section{DISCUSSION}

At present there is general agreement that the genus Haemophilus should be restricted to gram-negative, nonmotile, nonsporeforming rods with a requirement for hemin or other porphyrins (X factor) and/or for NAD (V factor) or other definable coenzyme-like substances $\langle 3,29$, $30)$. Results obtained in this study indicate the existence of a new species of the genus Haemophilus for which the name Haemophilus avium (a'vi.um. L.n. avis a bird; L. gen. pl. n. avium of birds) is proposed. This species differs from $H$. gallinarum and $H$. paragallinarum in its physiological, biochemical, and serological features and by its inability to cause infectious coryza of chickens $(4,9-12,21,23,24,28,30)$. The characteristics which distinguish $H$. avium from $H$. paragallinarum are presented in Table 3. Some properties of $H$. avium are identical with those of $H$. parasuis and $H$. parainfluenzae but not with those of other known Haemophilus species. However, the data presented by Kilian (16) show that $H$. parasuis differs from $H$. avium in its $\alpha$-fucosidase activity and by its weak or lack of fermentation of carbohydrates and from $H$. parainfluenzae in its oxidase and urease activities and negative $\alpha$-glucosidase reaction. ATCC 14385, previously identified as a strain of $H$. gallinarum, is here identified as a member of $H$. avium; it has the same physiological and biochemical properties as described for it by Kilian (16) under the strain number HK 381 (= NCTC $3438=$ ATCC 14385).

IPDH 2654, here designated as the type strain of $H$. avium, has been deposited in the American Type Culture Collection (ATCC) under the number 29546.

\section{REPRINT REQUESTS}

Address reprint requests to: Dr. K.-H. Hinz, Institute for Poultry Disease, The School of Veterinary Medicine, Hannover, Federal Republic of Germany.

\section{LITERATURE CITED}

1. Biberstein, E. L., P. D. Mini, and M. G. Gills. 1963. Action of Haemophilus cultures on $\delta$-aminolevulinic acid. J. Bacteriol. 86:814-819.

2. Biberstein, E. L., and D. C. White. 1969. A proposal for the establishment of two new Haemophilus species. J. Med. Microbiol. 2:75-78.

3. Biberstein, E. L., and K. Zinnemann. 1971. Report (1966-1970) of the Subcommittee on the Taxonomy of Haemophilus to the International Committee on Nomenclature of Bacteria. Int. J. Syst. Bacteriol. 31:133-134.
4. Cowan, S. T. 1974. Haemophilus, p. 117-119. In Cowan and Steel (ed.), Manual for identification of medical bacteria, 2nd ed. Cambridge University Press, Cambridge.

5. De Blieck, L. 1931. Een haemoglobinophile bacteria als oorzaak van coryza infectiosa gallinarum. Tijdschr. Diergeneeskde. 58:310-314.

6. Delaplane, J, P., L. E. Erwin, and H. O. Stuart. 1934. A hemophilic bacillus as a cause of an infectious rhinitis (coryza) of fowls. R.I. Agric. Exp. Stn. Bull. 244:1-12.

7. Delaplane, J. P., L. E. Erwin, and H. O. Stuart. 1938. The effect of the X-factor, of sodium chloride, and of the composition of the nutrient media upon the growth of the fowl coryza bacillus, Haemophilus gallinarum. J. Agric. Res. 56:219-226.

8. Elliot, C., and M. R. Lewis. 1934. A hemophilic bacterium as a cause of infectious coryza in the fowl. J. Am. Vet. Med. Assoc. 37:878-888.

9. Hinz, K.-H. 1973. Beitrag zur Differenzierung von Haemophilus-Stämmen aus Hühnern. I. Mitteilung: Kulturelle und biochemische Untersuchungen. Avian $\mathrm{Pa}$ thol. 2:221-229.

10. Hinz, K.-H. 1973. Beitrag zur Differenzierung von Haemophilus-Stämmen aus Hühnern. II. Mitteilung: Serologische Untersuchungen im Objektträger-Agglutinations-Test. Avian Pathol. 2:269-278.

11. Hinz, K.-H. 1975. Beitrag zur Differenzierung von Haemophilus-Stämmen aus Hühnern. III. Mitteilung: Pathogenitätsprüfung an Hühnerküken. Avian Pathol. 4:213-226.

12. Hinz, K.-H. 1976. Beitrag zur Differenzierung von Hae. mophilus-Stämmen aus Hühnern. IV. Mitteilung: Untersuchungen über die Dissoziation von Haemophilus paragallinarum. Avian Pathol. 5:51-66.

13. Holländer, R., and W. Mannheim. 1975. Characterization of hemophilic and related bacteria by their respiratory quinones and cytochromes. Int. J. Syst. Bacteriol. 25: $102-107$.

14. Kersters, K., and J. DeLey. 1971. Enzymatic test with resting cells and cell-free extracts, p. 44. In J. R. Morris and D. W. Robbins (ed.), Methods in microbiology, vol. 6A, p. 44. Academic Press Inc., London.

15. Kilian, M. 1974. A rapid method for the differentiation of Haemophilus strains. The porphyrin test. Acta Pathol. Microbiol. Scand. Sect. B 82:835-842.

16. Kilian, M. 1976. A taxonomic study of the genus Haemophilus with the proposal of a new species. J. Gen. Microbiol. 93:9-62.

17. Kilian, M., and P. Bülow. 1976. Rapid diagnosis of Enterobactericeae. 1. Detection of bacterial glycosides. Acta Pathol. Microbiol. Scand. Sect. B 84:245-251.

18. Kovács, N. 1956. Identification of Pseudomonas pyocyanea by the oxidase reaction. Nature (London) 178:703

19. Lautrop, H. 1960. Laboratory diagnosis of whoopingcough of Bordetella infections. Bull. WHO 23:15-35.

20. Nelson, J. B. 1932. Etiology of an uncomplicated coryza in the domestic fowl. Proc. Soc. Exp. Biol. Med. 30:306-307.

21. Page, L. A. 1962. Haemophilus infections in chickens. 1. Characteristics of 12 Haemophilus isolates recovered from diseased chickens. Am. J. Vet. Res. 23:85-95.

22. Page, L. A., A. S. Rosenwald, and F. C. Price. 1963. Haemophilus infections in chickens. IV. Results of laboratory and field trials of formalinized bacterins for the prevention of disease caused by Haemophilus gallinarum. Avian Dis. 7:239-256.

23. Pittman, M. 1957. Genus IV. Haemophilus Winslow et al., 1917, p. 406-413. In R. E. Buchanan and N. E. Gibbons (ed.), Bergey's manual of determinative bacteriology, 7th ed. The Williams and Wilkins Co., Baltimore.

24. Roberts, D. H., B. S. Hanson, and L. Timms. 1964 Observations of the incidence and significance of Hae- 
mophilus gallinarum in outbreaks of respiratory disease among poultry in Great Britain. Vet. Rec. 76:1512-1516.

25. Schalm, O. W., and J. R. Beach, 1936. Cultural requirements of the fowl-coryza bacillus. J. Bacteriol. 31:161-169.

26. Schalm, O. W., and J. R. Beach. 1936. Studies of infectious coryza of chickens with special reference to its etiology. Poult. Sci. 15:473-482.

27. Yamamoto, R., and D. T. Somersett. 1964. Antibody response in chickens to infection by Haemophilus gal linarum. Avian Dis. 8:441-453.

28. Yamamoto, R. 1975. Infectious coryza, p. 52-59. S. B. Hitchner et al. (ed.), Isolation and identification of avian pathogens. Arnold Printing Co., Ithaca, N.Y.

29. Zinnemann, K. 1967. Report (1962-1966) of the Subcommittee on the Taxonomy of Haemophilus. Int. J. Syst. Bacteriol. 17:165-166.

30. Zinnemann, K., and E. L. Biberstein. 1974. Genus Haemophilus, p. 364-368. In R. E. Buchanan and N E. Gibbons (ed.), Bergey's manual of determinative bacteriology, 8 th ed. The Williams and Wilkins Co., Baltimore.

31. Zinnemann, K., K. B. Rogers, J. Frazer, and J. M. Boyce. 1968. A new V-dependent Haemophilus species preferring increased $\mathrm{CO}_{2}$ tension for growth and named Haemophilus paraphrophilus, nov. sp. J. Pathol. Bacteriol. 96:413-419. 